\title{
Maternal Hyperthyroidism and Neonatal Testicular Dysfunction
}

\author{
Ahmed R.G* \\ Division of Anatomy and Embryology, Zoology Department, Faculty of Science, Beni-Suef University, Beni- \\ Suef, Egypt
}

*Corresponding Author: Ahmed R.G, Division of Anatomy and Embryology, Zoology Department, Faculty of Science, Beni-Suef University, Beni-Suef, Egypt, Email: ahmedragab08@gmail.com

\section{HYPOTHESIS}

The functions of hypothalamic-pituitary-thyroid axis (HPTA) are warranted for the developing newborns(El-bakry et al., 2010; Ahmed, 2011, 2012a,b, 2013, 2014, 2015a-c, 2016a-d, 2017av, 2018a-r; Ahmed and Ahmed, 2012; Ahmed et al., 2008; 2010; 2012; 2013a,b, 2014, 2015a,b, 2018a,b; Ahmed and Incerpi, 2013;Van Hercket al., 2013; Ahmed and El-Gareib, 2014,Incerpi et al., 2014; Candelotti et al., 2015; De Vito et al., 2015; El-Ghareeb et al., 2016; Ahmed and ElGareib, 2017), specifically the developing testes (Gao et al., 2014; Rijntjes et al., 2017; Ahmed, 2018a). During the different developmental periods, the 3,5,3'-triiodothyronine (T3) and its receptors and transporters can regulate the proliferation of the Sertoli and Leydig cells, steroidogenesis, and testicular development and maturation (Buzzard et al., 2000; Krassas and Perros, 2003; Maran, 2003; Haider, 2004; Holsberger et al., 2005; Mendis-Handagama et al., 2005; Wajner et al., 2007, $2008 \& 2009$ ).

On the other hand, early observations have described the association between the hyperthyroidism and disorders in the testes (Krassas and Perros, 2003; Rijntjes et al., 2008; Wajner et al., 2009). In men, hyperthyroidism caused oligospermia, delayed the mobility of the spermatozoa (Clyde et al., 1976), and decreased the total sperm counts (Kidd et al., 1979), libido (Krassas et al., 2002) and semen quality (Hudson and Edwards, 1992). Another study reported that the Grave's disease damaged the sexual maturation, hypospermia, teratospermia, asthenospermia, necrospermia and oligospermia (Notsu et al., 1997). In addition, precocious ejaculation, erectile dysfunction, and sexual disorders were noticed during the hyperthyroidism (Carani et al., 2005; Krassas et al., 2008). These data are supported by Wajner et al. (2009) who emphasized that the volume and function of the prepubertal testicular were decreased due to the harmful effects of the hyperthyroidism. Similar data were reported by Van Haaster et al. (1993), Teerds et al. (1998), Ariyaratne et al. (2000), Mendis-Handagama et al. (2007), and Rijntjes et al. (2008) who demonstrated that daily administration of T3has been revealed the following: (1) reduction in the number of Sertoli cells; (2) premature cessation for the proliferation of Sertoli cells; and (3) progress in the development of Leydig cell progenitors and in the cell population of adulttype Leydig cell. On the other hand, the treatment of thyrotoxicosis might improve the density and motility of the sperm, but no change was observed in the morphology of the sperm (Krassas et al., 2002) or the erectile complaints (Krassas et al., 2008).

In the light of the above considerations, my data hypothesize several views. The adequate functioning of the maternal HPTA plays a significant role in the development of the neonatal testis (spermatogenesis, sperm mobility and eventually fertility). In addition, the maternal hyperthyroidism may directly or indirectly delay the morphogenesis and functional development of the neonatal testis. This may perturb the structure of the sperm, decrease the quality, and amount of the semen, and cause infertility. Thus, the management of the maternal hyperthyroidism can be necessary to prevent these syndromes. This would afford improvement in maximizing the fertility consequence. However, it remains to be shown whether the severity of the hyperthyroidism during the gestation may cause more persistent perturbations in the neonatal testes. The molecular, biochemical and developmental mechanisms are required to explore these abnormal conditions. 


\section{REFERENCES}

[1] Ahmed, O.M., Abd El-Tawab, S.M., Ahmed, R.G., 2010. Effects of experimentally induced maternal hypothyroidism and hyperthyroidism on the development of rat offspring: I- The development of the thyroid hormonesneurotransmitters and adenosinergic system interactions. Int. J. Dev. Neurosci. 28, 437-454.

[2] Ahmed, O.M., Ahmed, R.G., 2012. Hypothyroidism. In A New Look At Hypothyroidism. Dr. D. Springer (Ed.), ISBN: 978-953-51-0020-1), In Tech Open Access Publisher, Chapter 1, pp. 1-20.

[3] Ahmed, O.M., Ahmed, R.G., El-Gareib, A.W., El-Bakry, A.M., Abd El-Tawaba, S.M., 2012. Effects of experimentally induced maternal hypothyroidism and hyperthyroidism on the development of rat offspring: II-The developmental pattern of neurons in relation to oxidative stress and antioxidant defense system. Int. J. Dev. Neurosci. 30, 517-537.

[4] Ahmed, O.M., El-Gareib, A.W., El-bakry, A.M., Abd El-Tawab, S.M., Ahmed, R.G., 2008. Thyroid hormones states and brain development interactions. Int. J. Dev. Neurosci. 26(2), 147-209. Review.

[5] Ahmed, R.G., 2011. Perinatal 2, 3, 7, 8tetrachlorodibenzo-p-dioxin exposure alters developmental neuroendocrine system. Food Chem. Toxicology, 49, 1276-1284.

[6] Ahmed, R.G., 2012a. Maternal-newborn thyroid dysfunction. In the Developmental Neuroendocrinology, pp. 1-369. Ed R.G. Ahmed. Germany: LAP LAMBERT Academic Publishing GmbH \& Co KG.

[7] Ahmed, R.G., 2012b. Maternal-fetal thyroid interactions, Thyroid Hormone, Dr. N.K. Agrawal (Ed.), ISBN: 978-953-51-0678-4, In Tech Open Access Publisher, Chapter 5, pp. 125-156.

[8] Ahmed, R.G., 2013. Early weaning PCB 95 exposure alters the neonatal endocrine system: thyroid adipokine dysfunction. J. Endocrinol. 219 (3), 205-215.

[9] Ahmed, R.G., 2014. Editorial: Do PCBs modify the thyroid-adipokine axis during development? Annals Thyroid Res. 1(1), 11-12.

[10] Ahmed, R.G., 2015a. Chapter 1: Hypothyroidism and brain development. In advances in hypothyroidism treatment. Avid Science Borsigstr.9, 10115 Berlin, Berlin, Germany. Avid Science Publications level 6, Melange Towers, Wing a, Hitec City, Hyderabad, Telangana, India. pp. 1-40.

[11] Ahmed, R.G., 2015b. Hypothyroidism and brain developmental players. Thyroid Research J. 8(2), 1-12.

[12] Ahmed, R.G., 2015c. Editorials and Commentary: Maternofetal thyroid action and brain development. J. of Advances in Biology; 7(1), 1207-1213.

[13] Ahmed, R.G., 2016a. Gestational dexamethasone alters fetal neuroendocrine axis. Toxicology Letters, 258, 46-54.

[14] Ahmed, R.G., 2016b. Neonatal polychlorinated biphenyls-induced endocrine dysfunction. Ann. Thyroid. Res. 2 (1), 34-35.

[15] Ahmed, R.G., 2016c. Maternal iodine deficiency and brain disorders. Endocrinol. Metab.Syndr.5, 223.http: //dx.doi.org/1 0.4172/ 2161-1017.1000223.

[16] Ahmed, R.G., 2016d. Maternal bisphenol A alters fetal endocrine system: Thyroid adipokine dysfunction. Food Chem. Toxicology, 95, 168-174.

[17] Ahmed, R.G.,2017a. Developmental thyroid diseases and GABAergic dysfunction. EC Neurology 8.1, 02-04.

[18] Ahmed, R.G., 2017b. Hyperthyroidism and developmental dysfunction. Arch Med. 9, 4.

[19] Ahmed, R.G.,2017c. Anti-thyroid drugs may be at higher risk for perinatal thyroid disease. EC Pharmacology and Toxicology 4.4, 140-142.

[20] Ahmed, R.G.,2017d. Perinatal hypothyroidism and cytoskeleton dysfunction. Endocrino lMetabSyndr 6, 271.doi:10.4172/2161-1017 .1000271

[21] Ahmed, R.G., 2017e.Developmental thyroid diseases and monoaminergic dysfunction. Advances in Applied Science Research 8(3), 01-10.

[22] Ahmed, R.G., 2017f.Hypothyroidism and brain development.J. Anim Res Nutr.2(2), 13.

[23] Ahmed, R.G.,2017g. Antiepileptic drugs and developmental neuroendocrine dysfunction: Every why has A Wherefore. Arch Med 9(6), 2.

[24] Ahmed, R.G.,2017h. Gestational prooxidantantioxidant imbalance may be at higher risk for postpartum thyroid disease. Endocrinol Metab Syndr 6, 279. doi10. 4172/ 21 61-1017.1000 279.

[25] Ahmed, R.G.,2017i. Synergistic actions of thyroid-adipokines axis during development. Endocrinol MetabSyndr 6,280. doi: $10.4172 / 21$ 6 1-1017.1000280.

[26] Ahmed, R.G.,2017j. Thyroid-insulin dysfunction during development. International Journal of Research Studies in Zoology 3(4), 73-75. DOI:http://dx.doi.org/10.20431/2454-941X .0304010 .

[27] Ahmed, R.G.,2017k. Developmental thyroid diseases and cholinergic imbalance. International Journal of Research Studies in Zoology 3(4), 70-72. DOI: http:// dx.doi. org/10.20431/2454-941X.0 304009. 
[28] Ahmed, R.G.,20171. Thyroid diseases and developmental adenosinergic imbalance.Int $\mathrm{J}$ ClinEndocrinol 1(2), 053-055.

[29] Ahmed, R.G.,2017m. Maternal anticancer drugs and fetal neuroendocrine dysfunction in experimental animals. EndocrinolMetabSyndr 6, 281.doi:10.4172/2161-1017.1000281.

[30] Ahmed, R.G.,2017n. Letter: Gestational dexamethasone may be at higher risk for thyroid disease developing peripartum. Open Journal of Biomedical \& Life Sciences (Ojbili) 3(2), 01-06.

[31] Ahmed, R.G., 2017o.Deiodinases and developmental hypothyroidism. EC Nutrition $11.5,183-185$.

[32] Ahmed, R.G.,2017p. Maternofetal thyroid hormones and risk of diabetes. Int. J. of Res. Studies in Medical and Health Sciences 2(10), 18-21.

[33] Ahmed, R.G.,2017r. Association between hypothyroidism and renal dysfunctions. International Journal of Research Studies in Medical and Health Sciences 2(11), 1-4.

[34] Ahmed, R.G.,2017s. Maternal hypothyroidism and lung dysfunction. International Journal of Research Studies in Medical and Health Sciences 2(11), 8-11.

[35] Ahmed, R.G.,2017t. Endocrine disruptors; possible mechanisms for inducing developmental disorders. International journal of basic science in medicine (IJBSM)2(4), 157160.

[36] Ahmed, R.G., 2017u.Maternal thyroid hormones trajectories and neonatal behavioral disorders. ARC Journal of Diabetes and Endocrinology 3(2), 18-21.

[37] Ahmed, R.G., 2017v.Maternal thyroid dysfunction and neonatal cardiac disorders. Insights Biol Med. 1, 092-096.

[38] Ahmed, R.G., 2018a. Maternal hypothyroidism and neonatal testicular dysfunction. International Journal of Research Studies in Medical and Health Sciences 3(1), 8-12.

[39] Ahmed, R.G.,2018b. Maternal hypothyroidism and neonatal depression: Current perspective. International Journal of Research Studies in Zoology 4(1), 6-10. DOI: http://d x. doi.org/ 10.20431/2454-941X .0401002.

[40] Ahmed, R.G.,2018c. Non-genomic actions of thyroid hormones during development. App ClinPharmacolToxicol: ACPT-108. DOI: 10.29011/ACPT-109. 100008.

[41] Ahmed, R.G.,2018d. Maternal thyroid function and placental hemodynamics. ARC Journal of Animal and Veterinary Sciences 4(1), 9-13. DOI: http://dx.doi.org/10.20431/2455-2518 .04 01002.

[42] Ahmed, R.G.,2018e. Interactions between thyroid and growth factors during development.
ARC Journal of Diabetes and Endocrinology 4(1), 1-4. DOI: http://dx.doi.org/ 10.20431/ 2455-5983.0401001.

[43] Ahmed, R.G.,2018f. Maternal thyroid hormones and neonatal appetite. ARC Journal of Nutrition and Growth 4(1), 18-22. DOI: http://dx.doi.org/10.20431/2455-2550.0401005.

[44] Ahmed, R.G.,2018g. Genomic actions of thyroid hormones during development. ARC Journal of Diabetes and Endocrinology 4(1), 58. DOI: http://dx.doi.org/10.20431/24555983.0401002.

[45] Ahmed, R.G.,2018h. Dysfunction of maternal thyroid hormones and psychiatric symptoms. American Research Journal of Endocrinology. 2(1), 1-6.

[46] Ahmed, R.G.,2018i. Is there a connection between maternal hypothyroidism and developing autism spectrum disorders? ARC Journal of Neuroscience 3(1),5-8. DOI: http:// dx.doi.org/10.20431/2456-057X.030100 2.

[47] Ahmed, R.G., 2018j.Maternal thyroid dysfunctions and neonatal bone maldevelopment. American Research Journal of Endocrinology (in press) $\mathrm{xx}-\mathrm{xxx}$.

[48] Ahmed, R.G., 2018k. Maternal thyroid disorders and risk of neonatal seizure: Current perspective. ARC Journal of Neuroscience 3(1), 21-25. DOI: http://dx.doi.org/10.20431/2456057X.0301004

[49] Ahmed, R.G., 20181. Gestational dioxin acts as developing neuroendocrine-disruptor. EC Pharmacology and Toxicology 6.3, 96-100.

[50] Ahmed, R.G., 2018m.Maternal thyroid dysfunction and risk of neonatal stroke. ARC Journal of Animal and Veterinary Sciences 4(1), 22-26. DOI:http://dx.doi.org/10.20431/2455-2518. 0401004

[51] Ahmed, R.G.,2018n. Maternal thyroid disorders and developing skin dysfunctions. ARC Journal of Dermatology 3(1), 13-17. DOI: http://dx.doi.org/10.20431/2456-0022.0301005

[52] Ahmed, R.G.,2018o. Maternal hypothyroidismmilk ejections: What is the link? ARC Journal of Nutrition and Growth 4(1), 29-33. DOI: http://dx.doi.org/10.20431/2455-2550.0401007

[53] Ahmed, R.G.,2018p. Does maternal antepartum hypothyroidism cause fetal and neonatal hyponatremia? ARC Journal of Diabetes and Endocrinology 4(1), xx-xxx. DOI: http://dx. doi.org/10.20431/2455-5983.0401004

[54] Ahmed, R.G.,2018q. Maternal hypothyroidism and rheumatoid arthritis. International Journal of Research Studies in Medical and Health Sciences Volume 3(2), xx-Xxx.

[55] Ahmed, R.G.,2018r. Developmental thyroid and skeletal muscle dysfunction.ARC Journal of Diabetes and Endocrinology 4(1), xx-xxx. 
DOI: http://dx.doi.org/10.20431/2455-5983. 04 01003

[56] Ahmed, R.G., Abdel-Latif, M., Ahmed F., 2015a.Protective effects of GM-CSF in experimental neonatal hypothyroidism. International Immuno-pharmacology 29, 538543.

[57] Ahmed, R.G., Abdel-Latif, M., Mahdi, E., ElNesr, K., 2015b. Immune stimulation improves endocrine and neural fetal outcomes in a model of maternofetal thyrotoxicosis. Int. Immunopharmacol. 29, 714-721.

[58] Ahmed, R.G., Davis, P.J., Davis, F.B., De Vito, P., Farias, R.N., Luly, P., Pedersen, J.Z., Incerpi, S., 2013a. Nongenomic actions of thyroid hormones: from basic research to clinical applications. An update. Immunology, Endocrine \& Metabolic Agents in Medicinal Chemistry, 13(1), 46-59.

[59] Ahmed, R.G., El-Gareib, A.W. 2014.Lactating PTU exposure: I- Alters thyroid-neural axis in neonatal cerebellum. Eur. J. of Biol. and Medical Sci. Res. 2(1), 1-16.

[60] Ahmed, R.G., El-Gareib, A.W., 2017.Maternal carbamazepine alters fetal neuroendocrinecytokines axis. Toxicology 382, 59-66.

[61] Ahmed, R.G., El-Gareib, A.W., Incerpi, S., 2014. Lactating PTU exposure: II- Alters thyroid-axis and prooxidant-antioxidant balance in neonatal cerebellum. Int. Res. J. of Natural Sciences 2(1), 1-20.

[62] Ahmed, R.G.,El-Gareib, A.W., Shaker, H.M., 2018a.Gestational 3,3',4,4',5-pentach lorobiphenyl (PCB 126) exposure disrupts fetoplacental unit: Fetal thyroid-cytokines dysfunction. Life Sciences 192, 213-220.

[63] Ahmed, R.G., Incerpi, S., 2013. Gestational doxorubicin alters fetal thyroid-brain axis. Int. J. Devl. Neuroscience 31, 96-104.

[64] Ahmed, R.G., Incerpi, S., Ahmed, F., Gaber, A., 2013b. The developmental and physiological interactions between free radicals and antioxidant: Effect of environmental pollutants. J. of Natural Sci. Res. 3(13), 74-110.

[65] Ahmed, R.G.,Walaa G.H., Asmaa F.S., 2018b.Suppressive effects of neonatal bisphenol A on the neuroendocrine system. Toxicology and Industrial Health Journal (in press).

[66] Ariyaratne, H.B., Mendis-Handagama, S.M., Mason, J.I., 2000.Effects of triiodothyronine on testicular interstitial cells and androgen secretory capacity of the prepubertal rat.BiolReprod. 63, 493-502.

[67] Buzzard, J.J., Morrison, J.R., O’Bryan, M.K., Song, Q., Wreford, N.G., 2000.Developmental expression of thyroid hormone receptors in the rat testis. BiolReprod. 62, 664-669.
[68] Candelotti, E., De Vito, P., Ahmed, R.G., Luly, P., Davis, P.J., Pedersen, J.Z., Lin, H-Y., Incerpi, I., 2015. Thyroid hormones crosstalk with growth factors: Old facts and new hypotheses. Immun., Endoc. \&Metab. Agents in Med. Chem., 15, 71-85.

[69] Carani, C., Isidori, A.M., Granata, A., Carosa, E., Maggi, M., Lenzi, A., 2005.Multicenter study on the prevalence of sexual symptoms in male hypo- and hyperthyroid patients.J ClinEndocrinolMetab.90(12), 6472-9.

[70] Clyde, H.R., Walsh, P.C., English, R.W., 1976. Elevated plasma testosterone and gonadotropin levels in infertile males with hyperthyroidism. FertSteril. 27(6), 662-6.

[71] De Vito, P., Candelotti, E., Ahmed, R.G., Luly, P., Davis, P.J., Incerpi, S., Pedersen, J.Z., 2015.Role of thyroid hormones in insulin resistance and diabetes.Immun., Endoc.\&Metab. Agents in Med. Chem., 15, 8693.

[72] El-bakry, A.M., El-Ghareeb, A.W., Ahmed, R.G., 2010.Comparative study of the effects of experimentally-induced hypothyroidism and hyperthyroidism in some brain regions in albino rats.Int. J. Dev. Neurosci. 28, 371-389.

[73] El-Ghareeb, A.A., El-Bakry, A.M., Ahmed, R.G., Gaber, A., 2016.Effects of zinc supplementation in neonatal hypothyroidism and cerebellar distortion induced by maternal carbimazole. Asian Journal of Applied Sciences 4(04), 1030-1040.

[74] Gao, Y., Lee, W.M., Cheng, C.Y., 2014. Thyroid hormone function in the rat testis. Front.Endocrinol. 5, 188.

[75] Haider, S.G., 2004. Cell biology of Leydig cells in the testis. Int Rev Cytol. 233, 181-241.

[76] Holsberger, D.R., Kiesewetter, S.E., Cooke, P.S., 2005. Regulation of neonatal Sertoli cell development by thyroid hormone receptor alpha1.Biol. Reprod. 73, 396-403.

[77] Hudson, R.W., Edwards, A.L., 1992. Testicular function in hyperthyroidism. JAndrol.13(2),11 $7-24$.

[78] Incerpi, S., Hsieh, M-T., Lin, H-Y., Cheng, GY., De Vito, P., Fiore, A.M., Ahmed, R.G., Salvia, R., Candelotti, E., Leone, S., Luly, P., Pedersen, J.Z., Davis, F.B., Davis, P.J., 2014. Thyroid hormone inhibition in L6 myoblasts of IGF-I-mediated glucose uptake and proliferation: new roles for integrin $\alpha v \beta 3$. Am. J. Physiol. Cell Physiol. 307, C150-C161.

[79] Kidd, G.S., Glass, A.R., Vigersky, R.A., 1979. The hypothalamic-pituitary testicular axis in thyrotoxicosis.J ClinEndocrinolMetab. 48(5), 798-802.

[80] Krassas, G.E., Perros, P., 2003. Thyroid disease and male reproductive function. J. Endocrinol. Invest. 26, 372-380. 
[81] Krassas, G.E., Pontikides, N., Deligianni, V., Miras, K., 2002. A prospective controlled study of the impact of hyperthyroidism on reproductive function in males.J ClinEndo crinolMetab.87, 3667-71.

[82] Krassas, G.E., Tziomalos, K., Papadopoulou, F., Pontikides, N., Perros, P., 2008. Erectile dysfunction in patients with hyper- and hypothyroidism: how common and should we treat? J ClinEndocrinolMetab.93, 1815-9.

[83] Maran, R.R., 2003. Thyroid hormones: their role in testicular steroidogenesis. Arch Androl.49(5), 375-88.

[84] Mendis-Handagama, S.M., SirilAriyaratne, H.B., 2005.Leydig cells, thyroid hormones and steroidogenesis. Ind J Experim Biol. 43, 93962.

[85] Notsu, K., Ito, Y., Furuya, H., Ohguni, S., Kato, Y., 1997. Incidence of hyperprolactinemia in patients with Hashimoto's thyroiditis. Endoc J. 44(1), 89-94.

[86] Rijntjes, E., Gomes, M.L.M., Zupanič, N., Swarts, H.J.M., Keijer, J., Teerds, K.J., 2017. Transient hypothyroidism: Dual effect on adulttype Leydig cell and Sertoli cell development. Front. Physiol. 8, 323.

[87] Rijntjes, E., Wientjes, A.T., Swarts, H.J.M., De Rooij, D.G., Teerds, K.J., 2008. DietaryInduced Hyperthyroidism Marginally Affects Neonatal Testicular Development. J Androl 29, 643-653
[88] Teerds, K.J., de Rooij, D.G., de Jong, F.H., van Haaster, L.H., 1998. Development of the adulttype Leydig cell population in the rat is affected by neonatal thyroid hormone levels. BiolReprod. 59, 344-350.

[89] Van Haaster, L.H., de Jong, F.H., Docter, R., de Rooij, D.G., 1993. High neonatal triiodothyronine levels reduce the period of Sertoli cell proliferation and accelerate tubule lumen formation in the rat testis, and increase serum inhibin levels. Endocrinology 133, 755760 .

[90] Van Herck, S.L.J., Geysens, S., Bald, E., Chwatko, G., Delezie, E., Dianati, E., Ahmed, R.G., Darras, V.M., 2013.Maternal transfer of methimazole and effects on thyroid hormone availability in embryonic tissues. Endocrinol. 218, 105-115.

[91] Wagner, M.S., Wajner, S.M., Maia, A.L., 2008. The role of thyroid hormone in testicular development and function.J Endocrinol.199(3), 351-65.

[92] Wajner, S.M., dos Santos Wagner, M., Melo, R.C., Parreira, G.G., Chiarini-Garcia, H., Bianco, A.C., 2007. Type 2 iodothyronine deiodinase is highly expressed in germ cells of adult rat testis. J Endocrinol. 194(1), 47-54.

[93] Wajner, S.M., Wagner, M.S., Maia, A.L., 2009. Clinical implications of altered thyroid status in male testicular function. Arq Bras Endocrinol Metab. 53(8), 976-982.

Citation: Ahmed R.G. Maternal Hyperthyroidism and Neonatal Testicular Dysfunction.ARC Journal of Urology.2018; 3(1):6-10. doi:dx.doi.org/10.20431/2456-060X.0301002.

Copyright: (C) 2018 Authors. This is an open-access article distributed under the terms of the Creative Commons Attribution License, which permits unrestricted use, distribution, and reproduction in any medium, provided the original author and source are credited. 